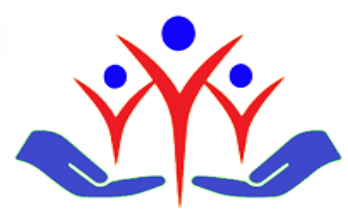

Research Article

\title{
Evaluation of monocyte to high-density lipoprotein cholesterol ratio in the manic state of bipolar disorder
}

Bipolar bozukluk manik dönemde monosit/yüksek dansiteli lipoprotein kolesterol oranının değerlendirilmesi

\section{Ali Metehan Caliskan ${ }^{\mathrm{a}}$, (Dusuf Cokunlu ${ }^{\mathrm{b}}$}

${ }^{a}$ Department of Psychiatry, University of Health Sciences, Konya Education and Research Hospital, Konya, Turkey

b Department of Psychiatry, Konya Numune State Hospital, Konya, Turkey

\begin{abstract}
Introduction: Bipolar disorder has been linked to abnormalities in the immune/inflammatory functions. Monocyte to high-density lipoprotein (HDL) cholesterol ratio (MHR) is used as chronic inflammation markers. The aim of this retrospective study was to investigate the MHR levels in manic patients with bipolar disorder.

Methods: The study included 100 male patients, 49 of whom were in the first episode and 51 of whom had multiple episodes, hospitalized with a diagnosis of bipolar disorder manic state and 50 healthy individuals with characteristics comparable to the patient group in terms of gender and age. MHR values were calculated on the basis of the obtained hemograms, and the results of the biochemistry blood tests and lipid panel analyses and recorded. Kruskal Wallis test was used to compare the MHR values among the first episode, multiple episodes, and healthy control groups. Results: There was no statistically significant difference between the patients and controls in terms of age, whereas the mean age of the patients who had multiple episodes was significantly higher than the first episode. MHR values were found to be statistically significantly higher in the first episode and multiple episodes group than healthy controls. There was no statistically significant difference between the MHR levels of the patients, who were in the first episode, and of the patients who had multiple episodes.

Conclusion: This study is consistent with the results of studies reporting inflammation in the manic episode of bipolar disorder and therefore may indicate the presence of inflammation in the manic episode.

Keywords: Bipolar disorder, HDL cholesterol, inflammation, monocyte, mania
\end{abstract}

\section{$\ddot{O} \mathbf{z}$}

Giriş: Bipolar bozukluk, immün/inflamasyon işlevlerindeki anormalliklerle ilişkilendirilmiştir. Monosit/yüksek yoğunluklu lipoprotein (HDL) kolesterol oranı (MHO), kronik inflamasyon belirteçleri olarak kullanılmaktadır. Bu retrospektif çalışmanın amacı, bipolar bozukluğu olan manik hastalarda MHO düzeylerini araştırmaktır.

Yöntem: Çalışmaya bipolar bozukluk manik dönem tanısı ile yatışı yapılan 49'u ilk epizot ve 51'i birden fazla epizot geçiren 100 erkek hasta ve cinsiyet ve yaş açısından hasta grubu ile benzer özellikte 50 sağlıklı birey dahil edildi. Alınan hemogram, biyokimya kanları ve lipid paneli tahlil sonuçlarına göre MHO hesaplanarak kaydedildi. MHO değerlerinin ilk epizot, birden fazla epizot ve sağlıklı kontrol grupları arasında karşılaştırılmasında Kruskal Wallis testi kullanıldı.

Bulgular: Hastalar ve kontroller arasında yaş açısından istatistiksel olarak anlamlı bir fark bulunmazken, birden fazla epizot geçiren hastaların yaş ortalaması ilk epizot hastalardan anlamlı derecede yüksekti. İlk epizot ve birden fazla epizot grubunda MHO değerleri sağlıklı kontrollere göre istatistiksel olarak anlamlı derecede yüksek bulundu. İlk atakta olan hastalar ile birden fazla epizot geçiren hastaların MHO düzeyleri arasında istatistiksel olarak anlamlı bir fark yoktu.

Sonuç: Bu çalışma bipolar bozukluğun manik döneminde inflamasyonu bildiren çalışmaların sonuçlarıyla tutarlıdır ve bu nedenle manik dönemde inflamasyonun varlığına işaret edebilir.

Anahtar kelimeler: Bipolar bozukluk, HDL kolesterol, inflamasyon, monosit, mani

\begin{tabular}{|c|c|c|c|c|}
\hline Received & Accepted & Published Online & Corresponding Author & E-mail \\
\hline February 7, 2021 & April 21, 2021 & May 5, 2021 & Ali Metehan Caliskan, M.D. & $\underline{\text { drmete@ @otmail.com }}$ \\
\hline Correspondence & $\begin{array}{l}\text { Dr. Ali Metehan Caliskan, Konya Eğitim ve Araştırma Hastanesi Psikiyatri Kliniği Yazır Mah. Turgut } \\
\text { Özal Cad. No:14/D Selçuklu / Konya, Turkey }\end{array}$ \\
\hline
\end{tabular}




\section{Introduction}

Bipolar disorder is a chronic, disabling mood disorder with recurrent manic and depressive episodes, and its prevalence is estimated to be around $1 \%$ [1]. Despite its high prevalence, its etiology is not known precisely; however, there is a growing number of studies indicating that oxidative stress and the changes in the inflammatory and immune systems are effective in its pathophysiology [2-4]. It has been reported in some studies that the pro-inflammatory cytokines increase and that the anti-inflammatory cytokines decrease during the manic period of bipolar disorder [5-7]. In the light of these studies, it has been suggested that bipolar disorder may be an inflammatory disease and that some biomarkers may become important determinants of the prognosis of bipolar disorder $[2,4]$.

Monocytes, which make up 3 to $8 \%$ of all leukocytes, are an important part of the immune system and are known to secrete pro-inflammatory and pro-oxidant cytokines during the inflammatory response [8-10]. Monocytes, which have the function of antigen-presenting in adaptive immunity, also have a considerable role in innate immunity. In bipolar disorder, the increase in monocyte count is a sign of chronic inflammation and might play a role in the disorder's pathophysiology $[8,11]$. High-density lipoprotein (HDL) shows antioxidant and anti-inflammatory effects by reducing the release of pro-inflammatory cytokines from monocytes and macrophages. HDL has anti-thrombotic and anti-apoptotic properties. In addition to these, HDL has anti-oxidant and anti-inflammatory effects by down modulating the release of pro-inflammatory cytokines from monocytes and macrophages [10].

Therefore, MHR has been studied as a marker of both oxidative stress and inflammation in many diseases [12-14]. In view of the foregoing, it is aimed with this study to evaluate the serum MHR level in manic state of bipolar disorder.

\section{Methods}

Study design

The present study was designed as a retrospective cross-sectional study and was carried out by scanning the medical records of patients in University of Health Sciences, Konya Education and Research Hospital. The medical records of 100 male inpatients, 49 of whom were in the first episode and 51 of whom had multiple episodes, aged between 18 and 65 years, who were diagnosed with bipolar disorder manic episode according to the International Classification of Diseases, Tenth Edition (ICD-10), or the Diagnostic and Statistical Manual of Mental Disorders, Fifth Edition (DSM-5) during the period between January 2018 and July 2020, were retrospectively reviewed. 50 healthy individuals, who did not have physical or psychiatric disorder, with characteristics comparable to the patient group in terms of gender and age were included the study.

\section{Sample inclusion criteria}

Patients aged 18-65 that were hospitalized with a diagnosis of bipolar disorder manic episode according to DSM-5 or ICD-10 diagnostic criteria and who had not used psychotropic drugs for at least the last six months were included in the study; whereas patients with a diagnosis of bipolar disorder and whose treatment is ongoing, patients with a diagnosis of mental retardation, patients with a history of chronic disease (autoimmuneinflammatory diseases, epilepsy, diabetes mellitus, cardiovascular, endocrinological, hepatic, renal, pulmonary, neurological diseases and malignancies), patients with a history of the hematological disease, patients with a history of corticosteroid, antilipidemic, immunosuppressive, and non-steroidal anti-inflammatory drugs use during the last month, patients with an acute infection, patients with alcohol and substance abuse problems, and the patients whose body mass index values were above $30 \mathrm{~kg} / \mathrm{m}^{2}$ were excluded from the study.

\section{Data collection}

The sociodemographic and clinical characteristics of the patients and their laboratory results were analyzed retrospectively from the electronic medical database of our hospital. Results of routine hemograms, biochemistry blood tests, and lipid panel analyses were reviewed within the scope of the study. Serum MHR level was computed as the ratio of monocyte count to HDL level. Blood samples were taken on hospitalization, before treatment was initiated.

\section{Data analysis}

Statistical analyses were performed using the Statistical Package for the Social Sciences (SPSS Inc., Chicago, IL, USA) version 20.0. Descriptive statistics included the mean and standard deviation was used for continuous data, whereas frequency and percentages were used for discrete data. The Kolmogorov-Smirnov test was conducted to evaluate the compliance of the data with a normal distribution. Chi-square test was carried out for categorical variables. The three independent groups were compared in terms of continuous variables, analyses of variance (ANOVA) test were used where there was a normal distribution within the groups, otherwise, the Kruskal Wallis test was used. The homogeneity of the variances was tested with Levene's test. Post-hoc Tukey and Mann-Whitney U-test with post hoc Bonferroni correction was performed to identify between group differences. A p value $<0.05$ (two-tailed) was considered statistically significant.

\section{Ethical approval, informed consent and permissions}

The study was approved by the clinical research ethics committee of Karatay University Faculty of Medicine (Approval Number E-300641901325-050.99, Date: 14 August 2020) and performed in accordance with the ethical standards laid down in the 1964 Declaration of Helsinki and its later amendments. 


\section{Results}

A total of 100 male inpatients, 49 of whom were in the first episode and 51 of whom had multiple episodes, were included in the study along with 50 healthy men. The mean age of the patients who were in the first episode of the patients who had multiple episodes, and of the controls were calculated as $27.51 \pm 6.75,34.20 \pm 9.79$, and $30.76 \pm 8.82$, respectively. There was no significant difference between the first episode patients and controls ( $\mathrm{p}=0.119)$, the multiple episode patients and controls $(\mathrm{p}=0.051)$ in terms of age, whereas the mean age of the patients who had multiple episodes was significantly higher than the mean age of the patients who were in the first episode $(\mathrm{p}<0.001)$. The total duration of illness was 91.65 \pm 76.34 month. Patients were hospitalized $4 \pm 2.25$ times on average. The mean number of manic mood episodes was $6 \pm 6.59$ and the numbers of depressive episodes were $0.84 \pm 1.70$. The demographic characteristics of the patient and control groups are given in Table 1 .

Table 1. Characteristics of patients with bipolar disorder and healthy controls

\begin{tabular}{|c|c|c|c|c|c|}
\hline & $\begin{array}{c}\text { First episode } \\
n=49\end{array}$ & $\begin{array}{l}\text { Multiple episodes } \\
\qquad \mathrm{n}=51\end{array}$ & $\begin{array}{l}\text { Healthy control } \\
n=50\end{array}$ & \multirow[t]{2}{*}{$\mathrm{p}$} & \multirow[t]{2}{*}{ Post-hoc } \\
\hline & & mean $\pm \mathrm{SD}, \mathrm{n}(\%)$ & & & \\
\hline Age & $27.51 \pm 6.75$ & $34.20 \pm 9.79$ & $30.76 \pm 8.82$ & $0.001^{*}$ & $\mathrm{ME}>\mathrm{FE}$ \\
\hline \multicolumn{6}{|l|}{ Education Status } \\
\hline$\leq 8$ years & $20(40.8 \%)$ & $25(49 \%)$ & & $0.410 * *$ & \\
\hline$>8$ years & $29(59.2 \%)$ & $26(51 \%)$ & & & \\
\hline Total duration of illness, month & & $91.65 \pm 76.34$ & & & \\
\hline Number of hospitalizations & & $4 \pm 2.25$ & & & \\
\hline Number of manic episodes & & $6 \pm 6.59$ & & & \\
\hline Number of depressive episodes & & $0.84 \pm 1.70$ & & & \\
\hline Seasonality & & $18(35.3 \%)$ & & & \\
\hline \multicolumn{6}{|l|}{ Mood stabilizer } \\
\hline Lithium & & $36(70.6 \%)$ & & & \\
\hline Valproic Acid & & $11(21.6 \%)$ & & & \\
\hline Other & & $4(7.8 \%)$ & & & \\
\hline
\end{tabular}

n: number; \%: column percentage; SD: standard deviation; ME: Multiple episodes; FE: First episode; *Kruskal-Wallis test was used; **Chi-square test was used.

The mean MHR levels of the patients who were in the first episode of the patients who had multiple episodes, and of the controls were calculated as $21.3 \pm 7,20.3 \pm 6.8$, and $10.2 \pm 2.3$, respectively. The results of Kruskal-Wallis test showed that there was a significant difference between the MHR levels of three groups ( $\mathrm{p}<0.001$ ). The Mann-Whitney U test revealed that MHR levels of the controls were statistically significantly lower than the patients who were in the first episode $(p<0.001)$ and then the patients who had multiple episodes $(p<0.001)$. No statistically significant difference was found between the patient groups in terms of MHR levels $(p=0.642)$. The comparisons between the three groups in terms of MHR levels and other blood parameters are given in Table 2.

Table 2. Comparison of blood count parameters between patients with bipolar disorder and healthy controls

\begin{tabular}{|c|c|c|c|c|c|}
\hline & $\begin{array}{c}\text { First episode } \\
\mathrm{n}=49\end{array}$ & $\begin{array}{l}\text { Multiple episodes } \\
\mathrm{n}=51\end{array}$ & $\begin{array}{l}\text { Healthy control } \\
\qquad \mathrm{n}=50\end{array}$ & $\mathrm{p}^{1}$ & Post-hoc \\
\hline \multicolumn{6}{|c|}{ mean $\pm \mathrm{SD}$} \\
\hline WBCs $\left(10^{3} / \mu 1\right)$ & $7.8 \pm 1.7$ & $8.3 \pm 1.5$ & $6.7 \pm 1.5$ & $<0.001 *$ & FE, ME $>$ HC \\
\hline Hemoglobin (g/dl) & $14.8 \pm 1.1$ & $14.7 \pm 1.4$ & $14.4 \pm 1.2$ & $0.186^{*}$ & \\
\hline Platelets $\left(10^{3} / \mu \mathrm{l}\right)$ & $225 \pm 55.1$ & $226.6 \pm 49.4$ & $280 \pm 45.2$ & $<0.001 *$ & HC $>$ FE, ME \\
\hline Neutrophils $\left(10^{3} / \mu 1\right)$ & $4.3 \pm 1.2$ & $4.6 \pm 1.2$ & $4 \pm 1.2$ & $0.079 *$ & \\
\hline Monocytes $\left(10^{3} / \mu 1\right)$ & $0.7 \pm 0.1$ & $0.7 \pm 0.1$ & $0.5 \pm 0.1$ & $<0.001 *$ & FE, $\mathrm{ME}>\mathrm{HC}$ \\
\hline Lymphocytes $\left(10^{3} / \mu \mathrm{l}\right)$ & $2.5 \pm 0.7$ & $2.7 \pm 0.9$ & $2.2 \pm 0.5$ & $0.023 * *$ & $\mathrm{ME}>\mathrm{HC}$ \\
\hline Triglyceride (mg/dl) & $95.2 \pm 43$ & $115.2 \pm 55.9$ & $95.7 \pm 33$ & $0.121 * *$ & \\
\hline LDL (mg/dl) & $94.7 \pm 33.3$ & $98.4 \pm 44.2$ & $103 \pm 26.6$ & $0.087 * *$ & \\
\hline HDL (mg/dl) & $38.6 \pm 8$ & $39.3 \pm 8.2$ & $51.7 \pm 6.5$ & $<0.001 *$ & $\mathrm{HC}>\mathrm{FE}, \mathrm{ME}$ \\
\hline MHR & $21.3 \pm 7$ & $20.3 \pm 6.8$ & $10.2 \pm 2.3$ & $<0.001 * *$ & FE, ME $>$ HC \\
\hline
\end{tabular}

n: number; SD: standard deviation, ME: Multiple episodes; FE: First episode; WBC: white blood cell; HDL: high-density lipoprotein; LDL: lowdensity lipoprotein; MHR: monocyte/ high-density lipoprotein ratio; *One-way analysis of variance test was used; **Kruskal-Wallis test was used.

\section{Discussion}

There is increasing evidence that inflammation plays a role in the pathophysiology of bipolar disorder, [15-17]. White blood cells and their subgroups are biological markers of inflammation, and activation of them leads to the release of inflammatory cytokines. The neutrophil to lymphocyte ratio (NLR) is considered as an important indicator of systemic inflammation in the literature [18-20]. NLR may be more useful than single subgroups of WBC in detecting the inflammatory response [20]. As a matter of fact, Ayhan et al. indicated that NLR levels of patients diagnosed with bipolar disorder in euthymic, depressive, and manic periods were higher than those of controls [21]. Yet in another study, Yildiz 
et al. reported that patients in euthymic and manic periods had higher NLRs compared to those of controls, however, that there was no significantly difference between the patients in depressive episode and controls [22]. Kalelioglu et al. also reported that NLR levels of both the patients in manic episode and the patients in euthymic state were higher compared to the controls [23]. In another study in which only patients in the manic episode were included, it was observed that the NLR levels increased during a manic episode [24].

On the other hand, a study of the recently published literature revealed that a new marker, the monocyte lymphocyte ratio (MLR), was started to be used in psychiatric studies [17]. Ozdin et al. demonstrated that patients diagnosed with bipolar disorder in the manic period had higher MLR values compared to the controls, and they have attributed this result to an increased inflammatory response in the body [17]. It has been suggested that the relationship between MLR and mood symptoms may be attributed to the pro-inflammatory cytokines released by activated monocytes/macrophages [25].

MHR is a new and ease accessible marker that can be easily computed by dividing the monocyte count to HDL (mg/dL). Both monocyte count and HDL cholesterol concentration $(\mathrm{mg} / \mathrm{dL}$ ) can be easily measured within the scope of the complete blood count and lipid panel, which are among the most widely used tests in our daily clinical practice [26]. In a number of studies, MHR has been deemed to be superior to WBC subtypes in detecting inflammatory response [14,27,28]. Monocyte count is the hematological parameter that increases during an inflammatory reaction. HDL cholesterol acts as an antioxidant and anti-inflammatory agent by decreasing the accumulation of macrophages, preventing the migration of monocytes, and increasing the NOS expression [29].

In our study, MHR levels were found to be higher in manic patients than healthy controls. These results are consistent with the results of the studies reporting inflammation during the manic state of bipolar disorder [7,11,16,17]. It has been suggested that the cumulative effect of both prolonged neuroprogression and allostatic load leads to an increase in systemic toxicity and inflammation during the late stages of bipolar disorder [30]. However, no significant difference was found between the MHR levels of the patients who were in the first episode and of the patients who had multiple episodes. Therefore, further studies may be needed to clarify the results.

\section{Limitations}

This study has some important limitations. The first limitation is that the study was designed as a retrospective and cross sectional. The retrospective nature of the study did not allow use of specific scales. The relationship between inflammation and the severity of the attacks the patients had suffered could not be evaluated since the hospital records of these patients did not include any scale as to the severity of the attacks. The second limitation is the lack of markers that indicate inflammation, such as cytokines or acute phase reactants. Finally, the third limitation is that only male patients and healthy controls were included in the study. Future research should evaluate the MHR levels of both male and female patients.

\section{Conclusion}

In our study, serum MHR levels of the patients diagnosed with bipolar disorder in the manic period were found to be higher than those of healthy individuals. Consistent with the literature, the results of our study suggest that inflammation may be part of the complex pathophysiology of bipolar disorder. However, prospective, randomized, and controlled studies that investigate serum MHR levels in different mood episodes are needed to draw definitive conclusions.

\section{Conflict of Interest: None}

Financial support: None

\begin{tabular}{|l|r|l|}
\hline \multicolumn{2}{|c|}{ Author Contributions } & \multicolumn{1}{c|}{ Author Initials } \\
\hline SCD & Study Conception and Design & AMC, YC \\
\hline AD & Acquisition of Data & AMC, YC \\
\hline AID & Analysis and Interpretation of Data & AMC \\
\hline DM & Drafting of Manuscript & AMC, YC \\
\hline CR & Critical Revision & AMC, YC \\
\hline
\end{tabular}

\section{References}

1. Vieta E, Berk M, Schulze TG, Carvalho AF, Suppes T, Calabrese JR, et al. Bipolar disorders. Nat Rev Dis Primers 2018;18008(4):1-16. https://doi.org/10.1038/nrdp.2018.8.

2. Fries GR, Walss-Bass C, Bauer ME, Teixeira AL. Revisiting inflammation in bipolar disorder. Pharmacol Biochem Behav 2019;177:12-9. https://doi.org/10.1016/j.pbb.2018.12.006.

3. Rosenblat JD, Brietzke E, Mansur RB, Maruschak NA, Lee Y, McIntyre RS. Inflammation as a neurobiological substrate of cognitive impairment in bipolar disorder: Evidence, pathophysiology and treatment implications. J Affect Disord 2015;188:149-59. https://doi.org/10.1016/i.jad.2015.08.058.

4. Stertz L, Magalhães PV, Kapczinski F. Is bipolar disorder an inflammatory condition? the relevance of microglial activation. Curr Opin Psychiatry. 2013;26(1):19-26. https://doi.org/10.1097/YCO.0b013e32835aa4b4.

5. Kim YK, Jung HG, Myint AM, Kim H, Park SH. Imbalance between pro-inflammatory and anti-inflammatory cytokines in bipolar disorder. J Affect Disord 2007;104(1-3):91-5. https://doi.org/10.1016/j.jad.2007.02.018.

6. Kupka RW, Breunis MN, Knijff E, Ruwhof C, Nolen WA, Drexhage HA. Immune activation, steroid resistancy and bipolar disorder. Bipolar Disord 2002;4 Supp 1:73-4. https://doi.org/10.1034/j.1399-5618.4.s1.29.x. 
7. Bai YM, Su TP, Tsai SJ, Wen-Fei C, Li CT, Pei-Chi T, et al. Comparison of inflammatory cytokine levels among type I/type II and manic/hypomanic/euthymic/depressive states of bipolar disorder. J Affect Disord 2014;166:187-92. https://doi.org/10.1016/j.jad.2014.05.009.

8. Barbosa IG, Rocha NP, Assis F, Vieira ÉL, Soares JC, Bauer ME, et al. Monocyte and lymphocyte activation in bipolar disorder: A new piece in the puzzle of immune dysfunction in mood disorders. Int J Neuropsychopharmacol 2014;18(1):pyu021. https://doi.org/10.1093/ijnp/pyu021.

9. Ancuta P, Wang J, Gabuzda D. CD16 + monocytes produce IL-6, CCL2, and matrix metalloproteinase-9 upon interaction with CX3CL1expressing endothelial cells. J Leukocyte Biol 2006;80(5):1156-64. https://doi.org/10.1189/jlb.0206125.

10. Efe TH, Arslan ED, Ertem AG, Yayla C, Felekoglu MA, Inci S, et al. The prognostic value of the Monocyte/HDL ratio in predicting shortterm mortality in patients with acute pulmonary embolism. Kosuyolu Heart J 2016;19:149-53. https://doi.org/10.5578/khj.23104.

11. Kirlioglu SS, Balcioglu YH, Kalelioglu T, Erten E, Karamustafalioglu N. Comparison of the complete blood count-derived inflammatory markers in bipolar patients with manic and mixed episodes. Bratisl Lek Listy 2019;120(3):195-9. https://doi.org/10.4149/BLL_2019_051.

12. Demirbas A, Elmas OF, Atasoy M, Tursen U, Lotti T. Can monocyte to HDL cholesterol ratio and monocyte to lymphocyte ratio be markers for inflammation and oxidative stress in patients with vitiligo? A preliminary study. Arch Dermatol Res 2020:1-8. https://doi.org/10.1007/s00403-020-02129-3.

13. Li N, Ren L, Wang JH, Yan YR, Lin YN, Li QY. Relationship between monocyte to HDL cholesterol ratio and concomitant cardiovascular disease in Chinese Han patients with obstructive sleep apnea. Cardiovasc Diagn Ther 2019;9(4):362-70. https://doi.org/10.21037/cdt.2019.08.02.

14. Mirza E, Oltulu R, Katipoglu Z, Mirza GD, Ozkagnici A. Monocyte/HDL Ratio and Lymphocyte/Monocyte Ratio in patients with pseudoexfoliation syndrome. Ocul Immunol Inflamm 2020;28(1):142-6. https://doi.org/10.1080/09273948.2018.1545913.

15. Beumer W, Gibney SM, Drexhage RC, Pont-Lezica, L., Doorduin, J., Klein, H.C., et al. The immune theory of psychiatric diseases: a key role for activated microglia and circulating monocytes. J Leukoc Biol 2012;92(5):959975. https://doi.org/10.1189/jlb.0212100.

16. Inanli I, Aydin M, Caliskan AM, Eren I. Neutrophil/lymphocyte ratio, monocyte/lymphocyte ratio, and mean platelet volume as systemic inflammatory markers in different states of bipolar disorder. Nord J Psychiatry 2019;73(6):372-9. https://doi.org/10.1080/08039488.2019.1640789.

17. Ozdin S, Usta MB. A comparison of inflammatory markers in manic and euthymic states of bipolar disorder. Nord J Psychiatry 2021;75(2):124-9. https://doi.org/10.1080/08039488.2020.1807048.

18. Imtiaz F, Shafique K, Mirza SS, Ayoob Z, Vart P, Rao S. Neutrophil lymphocyte ratio as a measure of systemic inflammation in prevalent chronic diseases in Asian population. Int Arch Med. 2012;5(1):2. https://doi.org/10.1186/1755-7682-5-2.

19. Melo MCA, Garcia RF, de Araújo CFC, Abreu RLC, de Bruin PFC, de Bruin VMS. Clinical significance of neutrophil-lymphocyte and platelet-lymphocyte ratios in bipolar patients: An 18-month prospective study. Psychiatry Res 2019;271:8-14. https://doi.org/10.1016/j.psychres.2018.10.077.

20. Katipoglu Z, Mirza E, Oltulu R, Katipoglu B. May Monocyte/HDL Cholesterol Ratio (MHR) and Neutrophil/Lymphocyte Ratio (NLR) be an indicator of inflammation and oxidative stress in patients with keratoconus?. Ocul Immunol Inflamm 2020;28(4):632-6. https://doi.org/10.1080/09273948.2019.1611876.

21. Ayhan MG, Dagistan AA, Tanrikulu CS, Bozdogan SY, Eren I. Increased neutrophil/lymphocyte ratio in suicide attempters. Anatolian J Psychiatry 2019;20:305-12. https://doi.org/10.5455/apd.8099.

22. Yildiz M, Batmaz S, Songur E, Sahin S, Demir O. Simple markers for subclinical inflammation in the different phases of bipolar affective disorder. Arch Clin Psychiatry 2016;43(6):143-6. https://doi.org/10.1590/0101-60830000000101.

23. Kalelioglu T, Akkus M, Karamustafalioglu N, Genc A, Genc ES, Cansiz A, et al. Neutrophil-lymphocyte and platelet-lymphocyte ratios as inflammation markers for bipolar disorder. Psychiatry Res 2015;228(3):925-7. https://doi.org/10.1016/j.psychres.2015.05.110.

24. Mayda H, Ahsen A, Bagcioglu E, Ozturk A, Bahceci B, Soyucok E, Effect of increased neutrophil-to-lymphocyte ratio (NLR) and decreased mean platelet volume (MPV) values on inflammation in acute mania. Neuro Psychiatry Arch 2016;53(4):317-20. https://doi.org/10.5152/npa.2016.10272.

25. Padmos RC, Hillegers MH, Knijff EM, Vonk R, Bouvy A, Staal FJ, et al. A discriminating messenger RNA signature for bipolar disorder formed by an aberrant expression of inflammatory genes in monocytes. Arch Gen Psychiatry 2008;65(4):395-407. https://doi.org/10.1001/archpsyc.65.4.395.

26. Uslu AU, Sekin Y, Tarhan G, Canakci N, Gunduz M, Karagulle M. Evaluation of Monocyte to High-Density Lipoprotein Cholesterol ratio in the presence and severity of metabolic syndrome. Clin Appl Thromb Hemost 2018;24(5):828-33. https://doi.org/10.1177/1076029617741362.

27. Liu H, Zhan F, Wang Y. Evaluation of monocyte-to-high-density lipoprotein cholesterol ratio and monocyte-to-lymphocyte ratio in ischemic stroke. J Int Med Res 2020;48(7):1-12. https://doi.org/10.1177/0300060520933806.

28. Bolayir A, Gokce SF, Cigdem B, Bolayir HA, Yildiz OK, Bolayir E, et al. Monocyte/high-density lipoprotein ratio predicts the mortality in ischemic stroke patients. Neurol Neurochir Pol 2018;52(2):150-5. https://doi.org/10.1016/j.pjnns.2017.08.011.

29. Murphy AJ, Woollard KJ. High-density lipoprotein: A potent inhibitor of inflammation: Frontiers in research review: Physiological and pathological functions of high-density lipoprotein, Clin. Exp. Pharmacol Physiol 2011;37:710-8. https://doi.org/10.1111/j.14401681.2009.05338.x.

30. Kapczinski NS, Mwangi B, Cassidy RM, Librenza-Garcia D, Bermudez MB, Kauer-Sant'anna M, Kapczinski F, Passos IC. Neuroprogression and illness trajectories in bipolar disorder. Expert Rev Neurother 2017;17(3):277-85. https://doi.org/10.1080/14737175.2017.1240615 